Janez Vrečko

\title{
Ut pictura poesis in konsi. Pesem kot slika, pesem kot prostor - nesporazumi
}

Ključne besede: ut pictura poesis, spacializacija, likovna pesem, tavole parolibere, prostor, čas, konstruktivizem, kons, semantična dominanta

Po Flakerju naj bi bila med konsi in likovno ustvarjalnostjo zelo tesna povezanost, konsi kot sinteza besednega gradiva in likovne forme naj bi bili od vsega začetka namenjeni tudi gledanju in ne le branju. Res je sicer, da so vsi pisani teksti tudi vidni, pri konsih pa je tako, da je vidnost njihov nujni sestavni del, ki dominira in se mu zato kratko in malo ni mogoče ogniti. Res je tudi, da je »konstruktivistično pesem prav tako mogoče "gledati«, kot je mogoče »brati« kakšno Magrittovo platno« (Weisberger, 1979, 401). Če hočemo konse dojeti celostno, jih moramo po Flakerju opazovati kot verbalne tekste $\mathrm{z}$ izrazitim nagnjenjem k ikoničnosti. Zato Flaker govori o Kosovelu avtorju literarnih tekstov, pa tudi slikarju - in pri tem izhaja iz spoznanja, da je znotraj avantgarde literatura neločljiva od slikarstva (gl. Flaker, 1988, 255). S tega stališča tudi Novak-Popova Kosovelove konse označuje kot »vsebinske in vizualnoreliefne konstalacije«, ki »napovedujejo vizualno poezijo« (Novak-Popov, 2002, 213). Podobno jih Poniž vidi kot »izrazit primer avantgardne poezije, ki združuje semantično in likovno komponento v novo pesniško podobo« (Poniž, 1998, 30). Podobni problemi so se pojavili pri opredelitvi Kosovelovih lepljenk, ki so vezane na kompozicijo in likovnost, medtem ko so konsi zunaj tega. Kdor to stori, meša slikovne lepljenke kot Montagebilder s konstruktivističnimi prostorskimi konsi. Te razlike se je Kosovel jasno zavedal že leta 1924, Černigoj pa šele čez nekaj let. Do tega je lahko prišlo, ker Černigoj ni znal uskladiti nasprotujočih si učenj dveh svojih učiteljev na Bauhausu, Kandinskega in Moholy-Nagya.

»Barvna razsežnost Kosovelovih podob je redukcionistična: reducirana je na temeljne barve: ni nenaravnih barv simbolistov in dekorativnih secesijskih barv, ni tudi impresionističnih oziroma verlainovskih nians. $\mathrm{V}$ njegovih podobah dominira bela barva: »belo« morje pomladnih noči / se razliva po poljih, vrtovih / (Kosovel, 1967, 115), »beli« so zidovi »ulic« »norišnic« (Kosovel, 1967, 135), »bele« so celo »barikade« 
(Kosovel, 1967, 151). Po zakonih kontrasta se mora pojaviti črna barva, tako da včasih dobimo vtis grafičnih listov: „Črni konji na belem snegu« (Flaker, 1988, 257). V pesmi Klic lirski subjekt ukazuje človeku na »belem stopnišču « ob »črnem stebru«, naj dvigne oči k »rdeči zastavi« (Kosovel, 1967, 267). ${ }^{1}$ Številnih tekstov torej ni več gradil na impresionističnem niansiranju, ampak na kromatskih kontrastih temeljnih barv, ki so jih uporabljali »konstruktivisti« (gl. Flaker, 1988, 249). Konstruktivistični kromatični kontrasti so postali v njegovih konsih vizualno nadvse izrazito kompozicijsko sredstvo. Podobno je ugotavljal tudi Zadravec. »Kar sta barva in črta slikarju, je barvna beseda Kosovelu.« (Zadravec, 1986, 269) Vse povedano kaže, da je Kosovel zelo »premišljeno gradil zaporedja in razmerja impulzivnih barvnih zvez. Pri tem se je najrajši odločal za kontrastiranje, za nekakšno barvno antiteznost (Zadravec, 1986, 272). Ocvirk pa je menil, da je Kosovel ustvaril kar teorijo o tehniki barv (gl. Kosovel, 1946-77, II, 637-639), ${ }^{2}$ ki jo je dobil pri ruskih konstruktivistih. »Kar sta barva in črta slikarju, je barvna beseda Kosovelu.« (Zadravec, 1986, 269)

Vendar pa so omenjeni avtorji spregledali, da sta bila pri Kosovelu barva in črta v konsih v službi arhitekture kot nadrejenega pojma, saj šele prostorskost in novo razumevanje časa dajeta konsom njihovo konstruktivistično podobo. Kosovel je v svoji prostorski poeziji kot »arhitekturi« izhajal iz Tatlinovega in Lisickijevega dela, iz PROUNov in veščev. V dnevniških zapiskih je Kosovel zapisal: »Vse je arhitektura / pesništvo, muzika, / slikarstva ni več.« (Kosovel, 1946-77, 718) Je Kosovel po naključju svoje tovrstne »pesmi« označil s kratico kons, sestavljeno iz štirih črk, in se s tem postavil ob bok stvaritvam, kot so Merz, mont, vešč, loks itd., katerih imena so tudi iz štirih črk? Očitno je s tem pojmom želel označiti nov pojav in mu ob povsem svojski etimologiji dati hkrati tudi avtorski pomen. Hkrati pa je $\mathrm{z}$ njim naznačil prehod od destrukcije h konstrukciji, kar je med vsemi avantgardističnimi gibanji dvajsetih let najbolj radikalno izpeljal prav ruski konstruktivizem. Kosovelov prehod "prek mostička nihilizma» (Kosovel, 1946-77, III, 398) je treba razumeti na ta način. S tem pa smo v osrčju problemov, ki jih je konstruktivizem videl $\mathrm{v}$ razlikovanju med kompozicijo in konstrukcijo ter $\mathrm{s}$ tem $\mathrm{v}$ redefiniciji pojma umetniškega dela. V dnevniške zapiske je Kosovel zabeležil tole:

Resnica Dobrota Lepota. Lepoto, okus, užitek moramo pri iskanju bistva umetnosti - izločiti. Lepota, okus, užitek, preveč relativne in variabilne za določevanje bistva umetnosti. Moramo jih izločiti (T). (Kosovel, 1946-77, III, 696)

Koga bi označevala črka T v oklepaju, lahko le ugibamo, a misel je blizu Tatlinu in celotnemu krogu ruskih konstruktivistov ter njihovi kritiki statusa umetniškega dela.

1 Oznaka se nanaša na Kosovelovo pesniško zbirko Integrali 26', izdano posthumno leta 1967.

2 Zbrano delo Srečka Kosovela: izhajalo od 1946 do 1977 v Ljubljani. Označeno je s številko zvezka in stranjo, npr. (III, 701). Uredil in z opombami opremil ga je Anton Ocvirk. 
$\mathrm{V}$ konsih je Kosovel polemiziral $\mathrm{z}$ enim temeljnih načel tradicionalne umetnosti, $\mathrm{z}$ načelom organske kompozicije in zaprtega dela oziroma teksta, saj ni šlo več samo za gola dejstva iz realnosti, ampak za njihovo prostorsko prezentacijo kot »organično konstruktivnost «.

Ob tem je treba opozoriti še na problem "pesmi kot slike«, »slikanja s črkami in besedami«. Tu gre za prastar problem, povezan s Horacijevo ut pictura poesis, z njegovo prostorsko in časovno razlago umetnosti, ki jo je pozneje znova obudil in povzel Lessing v svojem znamenitem Laokontu ali o poeziji in slikarstvu. Kosovel je v Dnevniku XVI jasno povedal, da »človek ne more več najti prostora v sliki (poudaril S. K.) «, zato išče "globine in lomljene ploskve: slikarstvo=arhitektura«. To pa doseže tako, da ustvari »trodimenzionalni predmet na $2 \mathrm{dim}$. ploskvi«, ne pa tako kot $\mathrm{v}$ futurizmu, ki je ustvarjal »dvodimenzionalni predmet na 2 dim. plosk.« (Kosovel, 1946-77, III, 769). Podobno tudi v Predavanju o besedi.

Prav v tem »lapidarnem « definiranju futurizma in konstruktivizma se nadvse jasno kaže, da je Kosovel odlično poznal obe gibanji in se jasno zavedal razlik med njima.

Ali je na temelju gornje miselne skice Kosovel kdaj imel "predavanje o besedi«, seveda ne vemo, da pa bi to predavanje izzvenelo $\mathrm{v}$ skladu $\mathrm{z}$ njegovo "gibljivo filozofijo« (Kosovel, 1946-77, III, 650) prostora, je popolnoma jasno. Zanimivo je, da je literarna veda na nekaterih ključnih mestih Kosovelovih rokopisov ostajala $\mathrm{v}$ območju nedorečenega in se raje zapletala v mišelovke o Kosovelovi terminološki, v ideološkem ozadju temelječi mimikriji in s tem še za nekaj časa podaljšala agonijo, ki se je že desetletja bila okrog Kosovelove literarne dediščine in njene umestitve v evropski avantgardistični pesniški prostor, ki je konstruktivističen.

Konstruktivistično pojmovanje prostora je treba zato ostro ločevati od futuristične spacializacije in tipografije, ki pomenita revolucijo v vizualnem, ne pa v prostorsko revolucionarnem smislu, $\mathrm{v}$ humaniziranju prostora in časa za človeka. Marinetti je v svoji zbirki Zang Tumb Tumb eksperimentiral z razmerjem med belino papirja in grafičnim zapisom, črke razporejal poševno, diagonalno, tudi po vsej podlagi, uporabljal različne tipografske trike, a pri tem ostajal $\mathrm{v}$ območju literarnega, se pravi v območju tradicionalno razumljenega literarnega prostora in časa. »Tipografska revolucija je naperjena zoper »tipografsko harmonijo natisnjene strani«, ki ovira »tok«, odtok, izbruh in prelet stila (poudaril J. V.) prek strani« (Troha, 1993, 34), v ničemer pa se ne dotakne recipienta in njegove "nekritične« drže do sveta. Dodaten dokaz za Marinettijevo "vizualno« literarno revolucijo najdemo tudi v tem, da se je v 
svojem početju sicer poskušal zavarovati pred očitki, da je le nadaljeval Mallarméjevo »dekorativno in izumetničeno estetiko«, v resnici pa je prevzel vse elemente Mallarméjeve »spacializacije« (espacement). Zanimivo je, da je ruski futurist Vladimir Šeršenjevič Marinettiju očital prav njegovo preveliko odvisnost od Mallarméja in mu svetoval iskanje posebne forme in ne le forsiranje vsebinskih sprememb, saj za svojo novo estetiko, lepoto hitrosti, ni našel prave forme.

Po drugi strani pa je treba priznati, da pri Marinettijevi tipografski revoluciji le ni šlo samo za ekspresivnost besede, ampak tudi za prvi korak k simultanosti dogajanja in $\mathrm{s}$ tem $\mathrm{k}$ novemu razumevanju prostora in časa $\mathrm{v}$ poeziji. Zato je $\mathrm{v}$ primeru $\mathrm{t}$. $\mathrm{i}$. "paroliber«, podob iz svobodnih besed, Marinetti svaril pred »obremenjevanjem s slikarstvom«. Vizualna spacializacija futuristov je torej daleč od tistega, kar bodo konstruktivisti razvili s svojim revolucionarnim pojmovanjem prostora in časa, zato je tudi zavedla nekatere naše raziskovalce, npr. Krečiča. Futuristični tekst je dobil "prostorsko« razsežnost šele z deklamacijo kot scensko gledališkim izvajanjem, kjer je deklamator obvladoval prostor in gib.

Še tako vizualen futuristični tekst je bil zamišljen za branje, bil je predvsem besedni in zvočni material. (Troha, 1993, 39)

Če se vrnemo k problemu ut pictura poesis, je že Marinetti v italijanskem futurizmu opažal, kako težko je bilo v poeziji realizirati »osvobojene besede«, ker so pesnike obremenile s slikarstvom. Zato so se poetološkega postopka "svobodnih besed « "polastili predvsem slikarji, ki so v t. i. 'tavolah paroliberah' vizualizirali svobodne besede $\mathrm{z}$ dodajanjem likovnih elementov« (Troha, 1993, 8) in s tem segli v območje likovne abstrakcije. Morda bi kdo skušal tudi ob tem povezati italijanski futurizem in Kosovelove konse, a to bi bilo hudo prenagljeno, kratkovidno in predvsem skregano $\mathrm{z}$ dejstvi.

Problem je bil namreč značilen za celotno zgodovinsko avantgardistično gibanje, saj se s problemom ut pictura poesis srečamo tudi v radikalni Kručonihovi zahtevi po prenaglašenosti likovnega in zvočnega elementa $\mathrm{v}$ poeziji, ki naj bi obšla pomen in smisel besed in pesem uveljavljala kot likovni in glasbeni dosežek, blizu abstrakciji ali pa kar izenačen z njo. Celo znotraj ruskega likovnega konstruktivističnega gibanja se je pokazalo, da pojem abstrakcije v slikarskem konstruktivizmu ni bil vprašljiv v enaki meri kot na področju poezije, kjer je prišlo do ostrega spora med "prostorskosemantičnim pojmovanjem« poezije Zelinskega, Selvinskega in Vere Inbrove na eni strani ter Čičerinovim abstraktno-likovnim razumevanjem na drugi strani. Ta spor je moral Kosovel vsaj v obrisih poznati.

Kosovel je namreč izhajal iz razumevanja pesmi, ki je morala ves čas ohranjati zvezo med izrazom in izraženim. Kot pesnik je ostajal »zvest« vlogi in pomenu, 
ki ga je za Slovence v njihovi zgodovini imela literatura, zato je premalo radikalen konstruktivizem v slikarstvu prepuščal Černigoju, v gledališču Delaku, atonalnost v muziki pa Kogoju. Sam pa načela mimesis v svoji ustvarjalnosti ni smel prestopiti. Celo v primeru, ko se je povsem evidentno skliceval na Malevičevo sliko Črn kvadrat na črnem ozadju, ki jo je lahko videl reproducirano v Zenitu, je s kontrastnostjo črne in bele barve povezoval »pomen«. »Črno barvo narišem poleg bele, ker vzbuja kontrast in ker ta kontrast nekaj pomeni. /.../ Vse, kar je v pesemci, mora imeti gotov pomen.« (Kosovel, 1946-77, III, 705) Na načelo mimesis se je še dodatno naslonil, ker je v svojih skrajnih pesniških eksperimentih ohranjal lirsko izpovedno noto, ki je pesem še dodatno ohranjala v pomenskem okrožju besede. Abstrakcija se je lahko formirala samo $\mathrm{v}$ naslovih nekaterih njegovih konsov, kar pa nikakor ni prispevalo $\mathrm{k}$ destrukciji njegove pesmi kot "pesemce«, ki mora imeti gotov pomen (isto). Zato ni res, da »sintaksa in kompozicija /.../ raznorodnega gradiva ne enotita, temveč puščata v kaotičnem stanju, ki ustreza grdoti razdrte evropske stvarnosti« (Novak-Popov, 2002, 212).

Kosovel je svojo poezijo tudi dinamiziral in kinetiziral, ji dopuščal preraščanje $\mathrm{v}$ arhitekturo, a ji v nobenem primeru ni odvzel njene semantične note, saj je pisal za znanega »socialnega naročnika«, ki je, komajda pismen, še zmeraj živel sredi »slamnatih streh« (Kosovel, 1967, 127), v industrijsko popolnoma nerazviti deželi. V enakih razmerah so delali tudi Tatlin in Malevič, Erenburg in El Lisicki, ki so vsi verjeli v umetniško in »človečansko« (Kosovelov izraz) silo konstruktivizma.

Arhitektonsko, prostorsko razsežnost Kosovelovih konsov pa še dodatno potrjuje dejstvo, da med konsi in integrali ni nikakršne zveze, čeprav je Ocvirk oboje povezal. S prostorsko zasnovanimi konsi bi bilo nemogoče prirediti recitacijski večer, kot je to predpostavljal Ocvirk, saj »samo poslušanje (konsov, op. J. V.) za celovito razumevanje teh besedil ne zadostuje. Zaposliti moramo vsaj še eno čutilo: oko.« (Šušteršič, 1988, 61) Tudi Zadravec s konstruktivizmom povezuje bralca in gledalca hkrati (Zadravec, 1986, 154).

Le kako bi lahko publika reagirala na kratice, matematična znamenja, formule in različne barve, na prostorske geometrijske like in celo na konkavne in konveksne skice ter »ogledalnost« kot bistvene strukturne elemente konsov? Z Integrali kot socialnorevolucionarnim ciklom pa bi Kosovel tudi storil tako, kot je napovedal. Bral bi jih javno in pri tem doživel uspeh ne le pri publiki, saj je šlo spet za integralne, torej celovite pesmi.

Kosovelu zelo ljub avtor Leonardo da Vinci je menil, da stvari, »ki pripadajo očem, ne gre razlagati očem«. Oko jih zazna samo od sebe, brez razlage. Avantgardistični Kosovelovi konsi so potemtakem tesno povezani s potrebo po njihovem vizualnem 
in s tem prostorskem dojemanju, zato jih je Kosovel želel objaviti le v specializiranem glasilu Konstrukter, KONS, pozneje pa v zbirki Ikarov sen. Verjetno pa bi bilo za konse najbolje, če bi jih natisnili v faksimilirani, torej predgutenbergovski podobi njegovega vehementnega rokopisa $\mathrm{z}$ vsemi pikturalnimi, matematičnimi, kemijskimi in drugimi znamenji, ali pa če bi sam nadzoroval njihov natis. Morda mu je Grahor ali kdo drug namignil tudi kaj o rokopisnih izdajah ruskih pesnikov Kručoniha, Hlebnikova, Čičerina itd.

Kosovel se je vsega tega zavedal, zato včasih ni zaupal niti lastnemu rokopisu in ga je na nekaterih zanj ključnih mestih po enkrat, dvakrat ali celo večkrat podčrtal, nekatere besede ali verze $\mathrm{v}$ primerjavi z ostalim gradivom tudi do trikrat povečal in uporabil celo barvni svinčnik ali črnilo, vseskozi pa bdel nad pomensko razvidnostjo pesmi. »V času deformacije./Analiza, analiza« (Rdeči atom, Kosovel, 1946-77, II, 582). Poezija je kot arhitektura, kjer $\mathrm{z}$ "gibanjem pesem ni enolična in oživi« (Kosovel, 1946-77, III, 705). Takšna ustvarjalnost seveda nima nobene zveze s Kosovelovim poznavanjem Apollinairovih Kaligramov ali študije o likovni poeziji Antona Debeljaka, objavljene v Ljubljanskem zvonu, s futuristično, zenitistično in dadaistično ustvarjalnostjo itd. Prostorskosti (ne pa likovnosti!) Kosovel ni dosegal tako, da bi posnemal predmete

po njihovem videzu (steklenica, kozarec, drevesa). Vse to početje, ki se je kot likovna pesem uveljavilo že v antiki, a zatem $\mathrm{v}$ renesansi in $\mathrm{v}$ baroku, se mu je zdelo preveč igračkasto; zato se ni mogel navdušiti tudi za najnovejše oblike likovnega pesniškega abstraktizma, ker so bile po njegovem vsebinsko premalo razvidne, idejno preveč plehke. (Ocvirk v: Kosovel, 1946-77, II, 583) (poudaril J. V.)

Zato so njegova besedila ostajala le "navidezno nelogična«, a »so tem bolj delovala na bralca, ko se mu je razkril njihov pravi pomen « (poudaril J. V.) (Ocvirk v: Kosovel, 1946-77, II, 583). V tem smislu bi imel Kosovel gotovo številne pripombe na samovoljne grafične rešitve, ki sta jih uveljavila Ocvirk in Brumen v Integralih '26, ki povrh vsega s Kosovelovo »zamislijo« Integralov nimajo nikakršne zveze.

$\mathrm{V}$ tem vidimo še en dokaz, da Kosovel s svojimi konsi ne bi mogel javno nastopiti, saj je potreboval ne le aktivne poslušalce, ampak tudi aktivne bralce in gledalce, ki pa jih v primeru, ko bi samo on »recitiral« svoje konse, ne bi imel, saj bi jim umanjkala vizualna, gibljiva, prostorska razsežnost njegove konstruktivne poezije. Zato seveda ne drži misel, da Kosovelova "prostorska urejenost besedila še ne predpostavlja opustitev konvencionalnega literarnega branja $\mathrm{z}$ leve proti desni in od zgoraj navzdol« (Novak Popov, 2002, 231). Nasprotno, naravnost sili nas k temu. Ne pozabimo: Kosovel je v svojem prvem javnem nastopu, kjer je v predavanju Kriza definiral konstruktivizem in se pred javnostjo deklariral kot konstruktivist, bral svojo ekspresionistično Ekstazo smrti. 
Tudi numeracija Delakove revije Tank prepriča, da je konstruktivistična logika slovenske avantgarde asimilirala princip razumevanja prostora El Lisickega, kar se kaže v konstruktivistični tipografiji in verbalnem jeziku. Če se je to lahko dogodilo v Tanku leta 1927, se je pri Kosovelu udejanjilo v letu 1925 v njegovih prostorskih konsih.

Kosovel je z uporabo inženirskih skic, geometrijskega materiala, vizualnega poudarjanja in prostorskega prenašanja teže pesmi zdaj v spodnji del (Predmeti brez $d u s ̌ e$, Kons 5, Pesem št. X), zdaj na desno stran pesmi (Srce v alkoholu, Sferično zrcalo), zdaj v njeno sredino v poeziji uveljavljal temeljno, prostorsko zahtevo literarnega konstruktivizma, ki je pesnika izenačeval $\mathrm{z}$ inženirjem, umetnost pa $\mathrm{z}$ življenjem, kar je Kosovel povedal na več mestih, posebej jasno v obeh uvodnih člankih, ki ju je pripravil za revijo Konstrukter, v Članku ABC in v Psihologiji pokretov. Vsebina in forma sta tu združeni v učinkovito dopolnjujočo se celoto in ustrezata Kosovelovi znameniti definiciji konstruktivizma.

Za te namene mu jezik kraških kmetov ni več zadoščal, dopolniti ga je moral z jeziki, ki se slovenska literatura, še posebej lirika, dotlej v njih še ni preskušala. Nove jezikovne plasti je dobro obvladal, pesmi z njimi estetsko ni pokvaril. /.../ Vanje je stopilo grdo, ničevo v svojih trdih, golih besednih oblikah: gnoj, žajfa, puška, transformator, petrolej. (Zadravec, 1986, 188)

In to ne le kot semantične enote, ampak v arhitektonski prepletenosti pomena, prostora in "gibljive filozofije» (Kosovel, 1946-77, III, 650).

Tudi konstruktivist Čičerin je uporabljal fotomontažo, risbe, formule in števila. Vse to je po njegovem ustrezalo temeljnemu zakonu konstruktivizma - varčevanju s pesniškimi sredstvi. Njegova formulacija je temeljila v Spencerjevem ekonomskem principu in se pokrivala $z$ verbalizacijo v LCK-ju. Spencerja je namreč omenjal že Šklovski v razpravi Umetnost kot postopek in ga povezoval z izjavo Veselovskega: »Veličina stila je prav v tem, da nudi čim večjo množino misli in čim manjšo množino besed.« S tem v zvezi je tudi Andrej Beli govoril o zakonu varčevanja v literaturi (gl. Šklovski, 1984, 21). Pesniški znak je bil tako podrejen maksimalni obremenitvi na enoto organiziranega materiala, na minimalnem prostoru, ob neločljivi, povsem kratki, nadvse pregledni formi, ki nosi pomen (Čičerin, 1926). Ustvarjal je tekste, ki so povezovali raznovrstne likovne in jezikovne postopke: montažo, fotografijo, risbo, znamenja, formule, številke in enantiosemijo. To so bili predvsem teksti »za pesnike«. $\mathrm{Ob}$ analizi abecede kot sistema fonogramov, s pomočjo katerih se zvočni pojavi spreminjajo v vizualne, je Čičerin označil pisavo kot »izrodek« in zahteval neposredno vizualno opazovanje znakov, se pravi, da mora pesnik uporabljati vizualno slikovne znakovne sisteme, ki jih ob sorazmerju z linijami predstavljajo pikturalna znamenja. 
Kot smo ugotovili, je prav zato ostal na ravni kompozicije in se ni povzpel h konstrukciji ter bil zato izločen iz LCK-ja.

V tem duhu je že Lisicki uredil naslovnico prve številke revije Vešč, Gegenstand, Objet, kjer na rdeče-oranžni podlagi »črke letijo v prostoru«. Semantično vlogo imajo tudi interpunkcijska znamenja, masten tisk, navpično in diagonalno razporejanje naslovov ter uporaba števil, elementi, ki jih je tudi Kosovel s pridom uporabljal v svojih konsih, posebej v t. i. zrcalnih pesmih, kjer besede zunaj določil evklidskega prostora zares lahko lebdijo v prostoru.

Kot »stvar« je beseda osvobojena referencialnosti, kot »beseda« je osvobojena neposredne materialnosti. Če je estetska percepcija spreminjala stol, posteljo in mizo $\mathrm{v}$ čiste forme prostorskih občutij, potem črta, točka ali črka upravičeno nastopajo samostojno s svojim notranjim zvokom. Zato konstruktivizem predpostavlja izdelovanje stvari, ne zanima pa ga končni izdelek kot »delo«. Dokončno je v konstruktivizmu na tej hierarhični lestvici stopila najvišje arhitektura kot sinteza umetniške, socialne in tehnične prakse, ki bi lahko hitreje kot druge umetniške smeri prispevala $\mathrm{k}$ re-konstrukciji sveta in uvedbi novega načina življenja. $\mathrm{S}$ tem so padle meje med t. i. "prostorskima « umetnostma, kot sta arhitektura in kiparstvo, in »časovnimi umetnostmi«, glasbo, plesom in poezijo, pa tudi meje med duhovnimi in tehnično-inženirskimi disciplinami. O Horacijevi sintagmi ut pictura poesis ni bilo več mogoče govoriti. Prav tako tudi ne o Lessingovem teoremu v Laokontu ali o mejah poezije. Kosovel je v Konsu to avantgardistično tendenco sijajno povzel, ko je videl sintezo kulture, politike in umetnosti $\mathrm{v}$ »novi arhitekturi za človeka« in jo povezal s »človekom z rdečo srajco« (Kosovel, 1946-77, III, 715).

\section{Sivo}

Pesem z naslovom Sivo (Kosovel, 1967, 156) opozarja na »sivo« vzdušje v tedanji kulturni situaciji na Slovenskem in je kot nekatere Kosovelove konstrukcije v enem delu izrazito impresionistično intonirana, $v$ drugem delu pa se loteva problematike Balkana, ki ga ima za »temelje bodočnosti«. Gnoseološki aspekt pesmi je zajet v treh pravokotnikih, ki so označeni $\mathrm{z}$ ', ", in "', ter štirih premicah, od katerih je vsaka označena s črko $\mathrm{A}, \mathrm{A}^{\prime}, \mathrm{B}, \mathrm{B}$ ', pod tem pa sledita razlaga razmerij med $\mathrm{AA}^{\prime}$ in $\mathrm{BB}^{\prime}$ ter pojasnilo k vsakemu pravokotniku posebej.

Gre za temeljno težnjo konstruktivizma, da mora umetnik delovati »s svinčnico $\mathrm{v}$ roki, $\mathrm{z}$ očmi, ki so precizne kot ravnilo, $\mathrm{z}$ napetim duhom kot šestilo. /.../ Mi konstruiramo svoje delo, kot ga konstruira univerzum, in konstruira inženir svoje mostove, kot matematik svoje formule o tirnicah planetov.« (Gabo, Pevsner, 
1/97-1/100) Po Rodčenkovih besedah lahko konstruktivistični umetnik samo s pomočjo ravnila in šestila ukine "nepopolnost in pomanjkljivost slikarjeve roke», saj je »črta, linija nosilec konstruktivnega principa montažne organizacije materiala« (Rodčenko, 1978). Gre torej za »vdor druge znanstvene, funkcijske zvrsti - skice so figurativno sredstvo geometrije - v umetnostno. Tudi s tem se je Kosovel bližal konstruktivističnemu pojmovanju umetnosti, ki je pesnika v svojem racionalizmu primerjala s tehnikom « (Šušteršič, 1988, 75) oziroma inženirjem. Temu bi lahko rekli tudi uporaba inženirskih skic v poeziji, s katero se srečamo pri vseh pomembnejših konstruktivističnih pesnikih.

Ne gre spregledati, da se v konsu Sivo ostrim pravokotniškim formam postavlja po robu zaobljena velika črka »B«. Zaobljenost in mehkoba črke »B« po načelu matematične enačbe povzema dva elementa: AKTIVNOST in BALKAN. Ne pa tudi DINAMIZMA.

Pojma»dinamizem«in »aktivnost«sta pripadala tako rekočvsem avantgardističnim gibanjem, z Balkanom pa se je Kosovel neposredno skliceval na zenitizem. Balkan je bil zanj poseben prostor dinamizma in aktivnosti, zato ga je še dodatno označil z nenavadno veliko črko » $B$ «, ki po velikosti obsega aktivnost in Balkan skupaj. Zanesljivo pa Kosovel z veliko črko » $B$ « ni želel označiti le Balkana, ampak tudi in predvsem svojega najljubšega zenitističnega pesnika Branka Ve Poljanskega, za katerega je v svoj Dnevnik zapisal: »Ljubim zenitiste/a ne zenitizma« (Kosovel, 1946-77, III, 724).

Psevdonim Poljanski naj bi Branko Micić, brat glavnega urednika Zenita Ljubomirja Micića, prevzel zato, ker je bil rojen v vasi Poljane pri Glini na Hrvaškem. »Njegova inicialka imena je bila $B$, a se je podpisoval V. ali Ve Poljanski.« (Batušić, 1971, 2, 702) To nas povezuje s konsom Sivo in z igro, v katero nas je zapeljal Kosovel. Njegova inicialka je bila torej v latinici » $B$ «, kar je bilo v cirilici » $V$ «. Ker je bil Srb, je $\mathrm{v}$ cirilski abecedi črka $\mathrm{B}$ označevala črko $\mathrm{V}$ in $\mathrm{s}$ tem še dodatno poudarjala avtorjevo balkansko barbarogenijskost nasproti Vergiliju kot očetu latinskega Zahoda, na kar je v njegovem podpisu namigovala črka »V« ali »Ve«. Svojo cirilsko, balkansko inicialko je torej Poljanski povezoval z Vergilijem, s tem pa ironiziral propadlo zahodno Evropo in hkrati propagiral svoj barbarski Vzhod. Na to dejstvo v konsu Sivo do danes ni opozoril še nihče, čeprav je imelo prav preigravanje imena Micićevega mlajšega brata veliko vlogo v Kosovelovi poeziji, prispevalo pa je tudi k temu, da se je Kosovel kot avantgardist večkrat poimenoval z imenom rimskega retorja Kvintilijana (gl. Kosovel, 1946-77, III, 704). Tudi tu je v ozadju dvojen pomen. Vemo, da bi moral biti Kosovel kot peti otrok v družini na župnikovo željo krščen s tem imenom, a je na prigovarjanje botra dobil ime Feliks Josef. »Na petega dne v tednu se mu je rodil 5 otrok. (Kosovel, 1946-77, III, 614) Je znameniti Kons:5 Kosovel posvetil samemu sebi? Je to Kvintilijanov 
konstruktivistični exegi monumentum? Je Kvintilijan res njegov »kristalni dvojček « (Kosovel, 1946-77, III, 666) ali »kristal z mnogimi ploskvami« (Kosovel, 1946-77, III, 754), kjer kristal razumemo kot transparenten material, ki je Gabu omogočil njegove prostorske konstrukcije? Navsezadnje se je Kosovel ob Članku $A B C$, ki ga je napisal za revijo Konstrukter, podpisal kot Kvintilijan (gl. Kosovel, 1946-77, III, 704). Tudi Kosovel je podobno kot Branko Ve Poljanski z Balkana s svojim avantgardističnim psevdonimom segel k svojim zahodnim, latinskim koreninam in zoper njih sprožil »konstruktivistično zaroto. A B C.« (Kosovel, 1946-77, III, 755)

Kosovel je očitno vedel, koga je v konsu Sivo označil z nenavadno veliko črko $» B$ «ter $\mathrm{z}$ njo povezal aktivnost in Balkan. Za aktivnost na Balkanu je bil po njegovem mnenju najbolj zaslužen prav Branko V.(e)(rgil) Poljanski. Če dinamizem in aktivnost iz prvih dveh pravokotnikov s trojnim enačajem izenačimo z Balkanom, kot je to storil Kosovel, in pri tem to aktivnost na Balkanu predstavlja prav $B$ «, se pravi Branko Poljanski, bo prišlo do »realnega dela«, ki je »temelj bodočnosti«.

Ob vztrajanju le pri dinamizmu bi ostali le v »ekspresionizmu življenja«, predajali bi se le depresijam $\left(A A^{\prime}\right)$, kar je Kosovel v tem času že najodločneje zavračal, saj je bil zanj ekspresionizem mrtev. Tudi gola aktivnost, ki ne bi bila zazrta v bodočnost, bi bila obsojena na propad, na »brezzračen prostor«, povezan z depresijami v gospodarstvu in politiki (BB').

$\mathrm{V}$ tem verzu se skriva tudi drzna in radikalna obsodba revolucije, predvsem tiste, ki je bila Kosovelu najbližja, oktobrske rdeče v Sovjetski zvezi, ki je v tem času že povzročila "gospodarsko in politično depresijo«, saj je Rusija iz žitnice Evrope čez noč postala dežela lakote in bede. $S$ tem je bil povezan tudi položaj avantgardističnih umetnikov, ki so sicer težili v »brezzračni prostor «, v kozmos, dejansko pa so morali slediti t. i. socialnemu naročilu, s čimer so prihajali v nerazrešljiv konflikt s partijsko politično oblastjo. To nasprotje je Kosovel sijajno upesnil s sintagmama »slamnate strehe« in s »tovarno svetiščem« (Kosovel, 1967, 276).

O vsem tem je Kosovel razmišljal in pisal v času, ko po Leninovi smrti večini evropskih intelektualcev še ni bilo jasno, kaj se je v resnici dogajalo v Sovjetski zvezi in so do nje brez sleherne distance gojili kar svečeniško občudovanje in romali v to prvo deželo socializma kot v obljubljeno deželo. Za večino je bila Sovjetska zveza dežela, kjer se sočasno dogajata umetniška in socialna rekonstrukcija. In v tem so velika imena, od Gida in Rollanda do Krleže, videla up tudi za zahodni svet. Kosovel v članku z naslovom Igo Gruden, ki ga je napisal 23. januarja 1926, opozarja, da »skoro vsa liberalna inteligenca /.../ je sprevidela, da po starih potih ne more v bodočnost, a novih ni ugledala. To je /po Kosovelovem mnenju/ usahnitev življenjskih sil, ki ne upajo in ne vidijo rešilnega dneva, ki prihaja $\mathrm{z}$ nastopom proletariata $\mathrm{v}$ svetovni zgodovini in 
z uveljavljanjem človečanskih pravic v Rusiji.« (Kosovel, 1946-77, III, 180) Takšno doktrinarno mnenje je povezano s Kosovelovim nastopom v Zagorju in s predavanjem Umetnost in proletarec, ki ga je imel med zagorskimi knapi.

Rusija je bila s svojo oktobrsko revolucijo glavna spodbuda za uveljavitev konstruktivizma, ker mu je omogočala sprotno funkcionalizacijo njegovih idej, s tem pa destruktivno načelo zahodnih avantgard spreminjala v konstruktivno. Prvi prodor ruske avantgarde $\mathrm{v}$ Berlinu je v organizaciji Narodnega komisarjata za izobrazbo tako za Lunačarskega in Majakovskega iz razumljivih razlogov pomenil politični uspeh, za zahodne avantgardiste in opazovalce pa prodor »strojne umetnosti«, ker so spregledali predvsem Tatlinov duhovnorevolucionarni naboj. V Rusiji je šlo res za dotlej neviden družbenopolitični eksperiment, $\mathrm{v}$ katerem so sodelovali avantgardisti, misleč, da gre tudi za veliko revolucijo Duha. Zato so imeli politično revolucijo za veliko priložnost nove umetnosti, kar pa se je kmalu pokazalo kot zabloda.

Ne smemo pozabiti, da je leta 1925 na skrivnosten način umrl Jesenin - danes je potrjeno, da ni šlo za samomor - in da je partija silovito posegala na vsa področja družbenega življenja. Razkol med umetnostjo in politiko je bil na dlani. Leninizem je neopazno prešel v stalinizem. Leta 1930 je tragično končal tudi Majakovski.

Zato je morala za Kosovela obstajati še tretja možnost, ki jo je prav tako mogoče razbrati $\mathrm{v}$ diagramu na dnu pesmi, nekakšnem pojasnjevalnem mestu, njenem gnoseološkem aspektu. Iz njega razberemo, da je mogoče depresijo preseči le $z$ akcijo in da so »temelji bodočnosti« vezani na Balkan in oprti na »realno delo«. »To nam potrdi dvakrat podčrtani predzadnji verz s trojnim enačajem na začetku, ki je v teoretični logiki znamenje za identifikacijo.« (Ocvirk v: Kosovel, 1946-77, II, 597) Skica s tremi pravokotniki nakazuje izhod:

Osebno in vsesplošno malodušje je mogoče rešiti. /.../ Pri tem se pomeni posameznih pravokotnikov, kakršne nam razkriva legenda $\mathrm{k}$ njim, pokrivajo s pomeni kitic, tako da lahko /.../ govorimo o paralelizmu. (Šušteršič, 1988, 74)

Prva kitica je tako vezana na »depresiven ekspresionizem življenja«, druga na aktivno željo po brezzračnem prostoru (ki ga ne bo bremenila gravitacija, op. J. V.), ki ga spremljajo depresije v gospodarstvu in politiki, tretja pa na "realno delo«, povezano $\mathrm{s}$ »temelji bodočnosti«. Rezultate bo dala samo sinteza dinamizma, aktivnosti in Balkana. Skice in črke tudi v tem konsu "prebijajo ravnino pesmi« in rastejo v prostor.

Zadnji verz kot nekakšen povzetek pesmi, njeno žarišče ali fokus, še dodatno potrjuje, da bo dobro zmagalo, saj je bil »Fernando, strah Asturije«, na slovenskih odrih pogosto uprizarjana ljudska igra $\mathrm{z}$ izrazito moralističnim poudarkom na koncu (gl. Ocvirk v: Kosovel, 1946-77, II, 597/8). Ocvirk takšen, za Kosovelove konse tipičen 
konec pesmi posrečeno imenuje »preskok v paradoks« (Kosovel, 1946-77, II, 597) in s tem potrjuje Kosovelovo zavestno odločenost, da je v svoje konse uvedel akcentuirano mesto, t. i. žarišče ali fokus, eno temeljnih zahtev Literarnega centra konstruktivistov (LCK-ja). 


\section{Literatura}

Batušić, S., Tridesetgodišnji dečak u gradu, v: Forum, Zagreb, 1971.

Flaker, A., Nomadi ljepote. Intermedijalne studije, Zagreb, 1988.

Gabo, Naum., Constructions, sculptures, peinture, dessins, gravure, Bern, 1961.

Kosovel, S., Integrali 26', Ljubljana, 1967.

Kosovel, S., Zbrano delo (ur. Ocvirk, A.), Ljubljana, 1946-1977.

Novak, Popov I., Premiki vizualne imaginacije v sodobni slovenski poeziji, v: Dwudziestowieczna ikonosfera $w$ literaturach europejskcih, Wizualizacija $w$ literaturze, Katowice, 2002.

Poniž, D., Slovenska zgodovinska avantgarda med Podbevškom in Tankom, v: Tank. Slovenska zgodovinska avantgarda, Ljubljana, 1998.

Šklovski, V., Umetnost kot postopek, v: Ruski formalisti (ur. Skaza, A.), Ljubljana, 1984.

Šušteršič, M., Likovnost Integralov Srečka Kosovela, v: Slavistična revija 36, Ljubljana, 1988.

Rodčenko A., Aestetic autobiografical and ideological writings, v: Creative camera international Year book (ur. Osman C., in Turner, P.), 1978.

Troha, V., Futurizem, Ljubljana, 1993.

Weisgerber, J., Les Avant-gardes littéraires, v: Canadian Review of Comparative Literature, Alberta, 1979.

Zadravec, F., Srečko Kosovel 1904-1926, Koper, Trst, 1986. 
Janez Vrečko

\section{Ut pictura poesis and konses. Poem as Picture, Poem as Space: Missunderstandings}

Keywords: ut pictura poesis, spatialization, visual poem, tavole parolibere, space, time, constructivism, kons, semantic dominance

One could hardly agree that Kosovel's konses anticipate visual poetry; that is, that they should serve as an obvious example of avantgarde poetry that synthesizes the semantic and visual dimension. Kosovel's konses belong to constructivism. The apex of the constructivist's scale of values is occupied by architecture, which is considered a synthesis of artistic, social, and technical practice and as such is also capable of reconstructing the world more rapidly than any other artistic current. In this synthesis, the limits between "spatial" arts such as architecture or sculpture and "temporal" arts such as music, dance, and poetry, as well as the limits between spiritual disciplines and technical engineering, disappear. There was no longer any chance of speaking about either Horace's syntagm ut pictura poesis or Lessing's theorem developed in his essay Laocoön: An Essay on the Limits of Painting and Poetry. Kosovel magnificently summarized this avantgarde tendency in Kons $Z$, and he recognized the synthesis of culture, politics, and arts in the domain of "new architecture for a man," binding it with "a man with a red shirt". Kons Sivo (Grey) articulates the basic tension of constructivism; that is, the dynamization and kinetization of poetry, and this is why the artist must act "with a sounding line in his hand, with eyes as precise as a ruler, with the soul as stretched as compasses" (Rodchenko). In this kons, sketches and letters also broke through the plane, growing into the space without losing their semantic dominating feature. 